\title{
Effectiveness Of Community Radio In Preservation And Promotion Of The Indigenous Culture
}

\section{Lokesh Sharma,}

Associate Professor, Department of Journalism \& Mass communication, Banasthali Vidyapith, Tonk, Rajasthan

\section{Dr. Hitendra Singh Rathore,}

Associate Professor, Department of Sociology, Banasthali Vidyapith, Tonk, Rajasthan.

\section{Dr. Girija Shanker Sharma,}

Former Head, Department of Journalism \& Mass Communication, Dr. B.R. Ambedkar University (UP).

\begin{abstract}
The main stream media has overlooked the importance of indigenous people and their culture. The failure of mainstream media in reaching and engaging the local communities has triggered the demand of Community based media. Over the years community media has been emerged as an alternate and viable option to the mainstream media. One of the popular forms of community media is the 'Community Radio' which is operated in a community, for the community and by the community members. In last two decades gradually but the community radio has been expanded throughout the country in India. Today, more than 250 community radio stations are operational in the country and most of these are serving the rural communities. This paper investigates the role of community radio stations in preserving and promoting the indigenous culture of the state of Rajasthan in India. The well known community radio stations of the Rajasthan state of India has been selected for the study. The findings of this study reveal most of the radio stations are playing an important role the preservation and promotion of folk art and culture of the state.
\end{abstract}

Keywords: Communication; media; community radio; folk culture; promotion

Article Received: 18 October 2020, Revised: 3 November 2020, Accepted: 24 December 2020

\section{Introduction}

Several communication studies have proved the contribution of community based media in community development. Dagron (2001) has discussed the potential of a community radio in terms of engaging the downtrodden communities of the society. Local radio is perhaps the most ideal approaches to arrive at marginalized in focused, valuable ways and in giving them a 'voice' that issues most being developed correspondence (Dagron, 2001). Local radio is one of the local area based media that are attempting to encourage more individuals as methods for strengthening at the grassroots (Pavarala and Malik, 2007).

A local radio broadcast is what is worked locally, for the local area, about the local area, and by the people of local area (Tabing, 2002). Local area radio gives a stage to people, gatherings, and networks to communicate their interests and encounters in a media-rich world.

Media the main network of intercultural communication worldwide has always been overlooking the significance of indigenous cultural practices and undermining tradition, local art and cultural identity. Community based media which can play a neutral and growth-centric role is the need of hour. In the era of market-driven industry and commercialization the presence of community media is very significant. Community media provide platform to those who do not have any other channels to express their concerns. It has evolved from dissatisfaction with mainstream media and which offer an alternative media channel for the community. Rennie (2006) emphasizes the role and value of community media as citizens' ability for self-representation and self-expression.

This paper is based on the research study I conducted on the community radio stations of Rajasthan with special focus on role of stations in preservation and promotion of folk culture. The study attempts to explore and analyse the programme content which focuses on folk music, 
art and culture of Rajasthan. The study also includes other community engagement activities organised by the CR station to motivate the folk artists/local talent which lead to promotion of local culture.

\subsection{Community Radio in India}

In India, till mid-1990s, All India Radio (AIR), the one and only public service broadcaster had been playing a vital role in disseminating relevant information to the people in the remotest parts of the country. However, it could not succeed in bringing the local communities into the process of development and consequently necessity of other alternative medium of radio broadcasting was realized. The comment of Supreme Court of India "airwaves are public property" ruled in historical judgment of February 1995, opened the doors of private and community broadcasting in India. This propelled the community radio movement in country and recognizing the potential of the medium of radio for the betterment of the community, in 2002, the Ministry of Information and Broadcasting, reported a strategy for allowing Community Radio licenses to instructive foundations. In 2003, the Government further opened it to instructive organizations both at the school and school levels. The country's first Community Radio Station began in February 2004 at Anna University, Chennai. The agents of NGOs, common social orders and deliberate associations scrutinized the approach and requested to open it for different partners. In November, 2006, Government of India altered the arrangement and included NGOs, common social orders and intentional associations to allow authorization for setting up CR stations. Today, in India, according to Ministry of Information and Broadcasting, Government of India in excess of 250 CRS are operational in the country.

\subsection{Community Radio in Rajasthan}

The journey of community radio service in Rajasthan began in January, 2005 when first community radio station of the state started at Banasthali Vidyapith (a deemed university for women) in Tonk district. At present (at the time of writing ) nine community radio stations are operational in the state, out of which four are being operated by the educational institutions and five are licensed to the NGOs. The list of operational community radio stations in Rajasthan is given in table 1.1

Table 1.1: Operational Community Radio Stations in Rajasthan

\begin{tabular}{|c|c|c|c|c|c|}
\hline S.No. & $\begin{array}{l}\text { Name of } \\
\text { CRS }\end{array}$ & MHz & Organization & Category & $\begin{array}{l}\text { Launch } \\
\text { Date }\end{array}$ \\
\hline 1. & $\begin{array}{l}\text { Alwar ki } \\
\text { Awaz }\end{array}$ & 90.8 & $\begin{array}{l}\text { I.E.T.Group of } \\
\text { Institutions, Alwar- } 301 \\
030\end{array}$ & NGO & 01.01 .2013 \\
\hline 2. & FM Sikar & 90.4 & $\begin{array}{l}\text { Ward No. 27, Shastri } \\
\text { Nagar, Rani Sati Road, } \\
\text { Sikar- } 332001\end{array}$ & NGO & 4-11-2018 \\
\hline 3. & Jayoti Vani & 91.2 & $\begin{array}{l}\text { Jayoti Vidyapeeth } \\
\text { Women's University, } \\
\text { Jaipur }\end{array}$ & Educational & 31.07 .2013 \\
\hline 4. & Kamalvani & 90.4 & $\begin{array}{l}\text { Kamalnishtha Sansthan, } \\
\text { Kolsia, ,Jhunjhunu- } 333 \\
042\end{array}$ & NGO & 22.11 .2012 \\
\hline
\end{tabular}




\begin{tabular}{|r|l|l|l|l|l|}
\hline 5. & Radio-7 & 90.4 & $\begin{array}{l}\text { International School of } \\
\text { Informatics and } \\
\text { Management,Jaipur - 302 } \\
020\end{array}$ & Educational & 07.03 .2005 \\
\hline 6. & $\begin{array}{l}\text { Radio } \\
\text { Banasthali }\end{array}$ & 90.4 & $\begin{array}{l}\text { Banasthali Vidyapith, } \\
\text { Tonk, Rajasthan - 304 } \\
\text { 022 }\end{array}$ & Educational & 09.01 .2005 \\
\hline 7. & $\begin{array}{l}\text { Radio } \\
\text { Madhuban }\end{array}$ & 90.4 & $\begin{array}{l}\text { Brahma Kumaris, Abu } \\
\text { Road, Sirohi - 307 510 }\end{array}$ & Educational & 14.03 .2011 \\
\hline 9. & Tilonia Radio & 90.4 & $\begin{array}{l}\text { Barefoot College, Tilonia, } \\
\text { Ajmer - 305 816 }\end{array}$ & NGO & 09.11 .2009 \\
\hline
\end{tabular}

(*Source: https://mib.gov.in/CommunityRadioCompendium )

\subsection{Folk culture of Rajasthan}

The local essence of art and culture can be observed throughout the Rajasthan state of India. Marwari, Rajasthani dialect is the key identity of folk culture in the state. Music has consistently been a vital piece of Rajasthani Culture. Being overwhelmed by ancestral gatherings previously, ancestral or people music assumes an important part in the way of life of Rajasthan. The mainstream and kaleidoscopic dance structure incorporates Ghoomar, Kalbeliya, Kathaputali, Bhopa, Chang, Teratali, Ghindar, Kachchighori, Tejaji, Parth, and a few others. The folk tunes of Rajasthan include the heroic tales, eternal love stories, and devotional songs. The utilization of customary instruments like dholak, sarangi, sitar, and others make Rajasthani music a genuine euphoric encounter for the audience members and music devotees. The little canvases, handiworks Tie-color works, zari work, weaving, reflect work on garments, utilization of valuable metals, and other metal works are a portion of the native types of workmanship and artworks. The way of life of Rajasthan is chiefly determined by its fairs and celebrations. Diwali, Gangaur, Teej, and Makar Sankranti are probably the most venerated celebrations in India's Desert Capital. The state has various occasions like Kite Festival, Desert Festival and Pushkar Mela.

\section{Literature Review}

Atton (2002) presented his study about the use of alternative media to preserve and promote the culture of their communities. He noticed that alternative media channels as a vehicle of participatory majority rule government, assumes an essential part in local area advancement. Local area media usually incorporates radio; TV; print; and PC organizations, however the nature and reason, paying little heed to the medium, conveys shared qualities. The foundations of local area radio lie in the advancement of optional media. Howley (2005) talks about the democratic potential of alternative media which enhance democracy and citizenship.

Dutta \& Ray (2009) found that more powerful broadcast groups overlook the interests and concerns of local audience while community radio caters their interests. Rennie (2006 p. 189) relates empowerment with the community media and pointed out that in the case of community media, empowerment can be understood as encouraging creativity and imagination, breaking individual's isolation and demystifying mass media. In 2015 a research study conducted by Ideosync Media in collaboration CEMCA and UNESCO evaluated the factors that impact the sustainability of Community Radio in the South Asia region. This 
study found that the community radio stations in the region are evolving strong community engagement practices that are leads towards social sustainability. The researchers recommended more work to become stronger and more independent media institutions.

\section{Objectives}

The key objective of the study was to investigate the role of community radio in preserving and promoting the folk culture of Rajasthan (India). Specifically, the study was aimed to

1. Analyse the programme content of community radio stations based on folk music, art and culture.

2. Identify the efforts being made by community radio stations to preserve and promote indigenous values and practices.

\section{Methodology}

The methodology adopted for this study is qualitative and the research method includes media observation, interviews with key people to explore the research questions. The primary data was collected through the interviews and secondary data was collected from different mass media sources like website, face book post and news articles. The data obtained from these sources were analyzed qualitatively. The data were coded and the contents were analyzed thematically. The flexibility of research design ensures maximum participation with minimum disruption which encourages community radio representatives to share information about the CRS.

\subsection{Selection of CRS}

Six community radio stations were selected using the purposive sampling method. The selection criteria for community radio station includes (1) Different models of community radio stations in Rajasthan (2) The location of station wherein community radio station situated in the rural areas or surrounded by the villages. The community radio stations selected for this study are Radio Banasthali 90.4 FM in Tonk district, Tilonia Radio 90.4 FM in Ajmer district, Radio Madhuban 90.4 FM in Sirohi district, Kamalvani 90.4 FM in Jhunjhunu district, Radio 7 in Jaipur district and Vagad Radio 90.8 FM in Banswara district of Rajasthan. All well-known community radio stations in the state have been serving the community for many years and hence are well placed and positioned in their respective communities. (SeeTable: 1.2)

Table1.2: Selected Community Radio Stations

\begin{tabular}{|r|l|l|l|}
\hline S.No. & Name of CRS & Address & Category \\
\hline 1. & Kamalvani & $\begin{array}{l}\text { Kamalnishtha Sansthan, Kolsia, } \\
\text {,Jhunjhunu- 333042, Rajasthan (India) }\end{array}$ & NGO \\
\hline 2. & Radio-7 & $\begin{array}{l}\text { International School of Informatics and } \\
\text { Management, Jaipur - 302020 } \\
\text { Rajasthan (India) }\end{array}$ & Educational \\
\hline 3. & Radio Banasthali & $\begin{array}{l}\text { Banasthali Vidyapith, } \\
\text { Tonk- 304022 Rajasthan (India) }\end{array}$ & Educational \\
\hline 4. & Radio Madhuban & $\begin{array}{l}\text { Brahma Kumaris, Abu Road, } \\
\text { Sirohi - 307510, Rajasthan (India) }\end{array}$ & Educational \\
\hline 5. & Tilonia Radio & $\begin{array}{l}\text { Barefoot College, Tilonia, } \\
\text { Ajmer - 305816, Rajasthan (India) }\end{array}$ & NGO \\
\hline 6. & Vagad Radio & $\begin{array}{l}\text { Kopda, Banswara- 327 001, Rajasthan } \\
\text { (India) }\end{array}$ & NGO \\
\hline
\end{tabular}




\subsection{Telephonic Interviews}

The telephonic interviews were conducted with the station in-charge, programming or production staff to gather information regarding community radio programmes and other efforts to promote folk art and culture. Questions related to name of programme/s, format and duration; language of the programme; other activity/event to promote folk art/culture; number of folk artists/antigens associated with the CRS as staff/volunteers; any group of folk artists/antigens associated with the CRS were asked during the interviews.

\section{Result and Discussion}

\subsection{Broadcast profile of CRS}

The broadcast profile of community radio stations reveal that most of popular programmes are being on aired in Hindi, Rajasthani and local language. Some of the radio stations are using local language like Radio Madhuban broadcast in adivasi, Kamalvani broadcast in shekhwati and Radio Vagad is broadcasting in Vagadi.

Kamalvani 90.4 FM broadcast 10 hours daily with an emphasis on skill development, sanitation \& cleanliness, disinfection and neatness, supportability of society, variety of nature, family government assistance framework, youngster and maternal wellbeing, social wrongs, social qualities, customary traditions of the general public and its government assistance viewpoint, tobacco free schools, fresco canvases and people culture of Shekhawati territory.

Table1.3: Broadcast Profile of Community Radio Stations

\begin{tabular}{|r|l|l|l|l|}
\hline \multicolumn{1}{l}{ S.No } & \multicolumn{1}{|c|}{ CRS } & Broadcast timings & Total Hours & Language of Broadcast \\
\hline 1. & Kamalvani & 6-11AM ; 5-10PM & $10 \mathrm{hrs}$. & Hindi and Rajasthani \\
\hline 3. & $\begin{array}{l}\text { Radio } \\
\text { Banasthali }\end{array}$ & $\begin{array}{l}\text { 7-11AM; } 12- \\
4 \mathrm{PM} ; 5-9 \mathrm{PM}\end{array}$ & $12 \mathrm{hrs.}$ & Hindi and Rajasthani \\
\hline 4. & $\begin{array}{l}\text { Radio } \\
\text { Madhuban }\end{array}$ & $\begin{array}{l}\text { 6AM-10.30PM } \\
10.30 \text { PM (onwards } \\
\text { repeat broadcast) }\end{array}$ & $24 \mathrm{hrs.}$ & Hindi, Marwari \& Adivasi \\
\hline
\end{tabular}




\begin{tabular}{|r|l|l|l|l|}
\hline 5. & Tilonia \\
Radio & $\begin{array}{l}7-9 \text { AM } \\
12-2 \text { PM } \\
6-9 \text { PM }\end{array}$ & 7 hrs. & Hindi and Marwari \\
\hline 6. & $\begin{array}{l}\text { Vagad } \\
\text { Radio }\end{array}$ & $\begin{array}{l}6 \text { AM - 01 PM } \\
5 \text { PM - 10 PM }\end{array}$ & 13 hrs. & Hindi and Vagadi \\
\hline
\end{tabular}

(Source:https://mib.gov.in/CommunityRadioCompendium2019.pdf)

\subsection{Programme content}

Radio stations broadcast programs based on folk art, music and culture frequently. Most of the Programs are on-aired in interactive formats which ensure the community participation and engagement. Some programs follow the contemporary format of infotainment in which folk songs are linked with the talks and discussion to entertain the listeners. Other programmes contain series of folk songs linked with the announcements, spots, jingles and promos .The local dialect and the local style of presentation add the favour local culture which creates a bonding with the listeners. Other formats like live phonein, storytelling and field recordings are also used to make the programmes interesting.

Table1.4: Programme content based on folk music/art/culture

\begin{tabular}{|c|c|c|c|c|}
\hline S.No. & Name of CRS & Programmes & Formats & Duration \\
\hline 1. & Kamalvani & $\begin{array}{l}\text { - Radio Maths, } \\
\text { - Apni-Dharti-Apna } \\
\text { Log, } \\
\text { - Apni choupal } \\
\text { - Maruras, } \\
\text { - Kuchh baten kuchh } \\
\text { geet }\end{array}$ & $\begin{array}{ll}\text { - } & \text { Discussion } \\
\text { - } & \text { Interviews } \\
\text { - } & \text { Field recording } \\
\text { - } & \text { Folk Music } \\
\text { - } & \text { Story with folk } \\
& \text { music }\end{array}$ & 6hours/day \\
\hline 2. & Radio 7 & $\begin{array}{l}\text { - } \text { Chokho Laage } \\
\text { - Rajasthan, } \\
\text { - } \text { Pamaaj Ki Awaz, } \\
\text { - } \quad \text { Kilkaari, } \\
\text { - } \text { Meethe Bol, } \\
\text { - } \text { Aisa Desh ho Mera }\end{array}$ & $\begin{array}{l}\text { - Live-phone in } \\
\text { - Field recording } \\
\text { - Discussion } \\
\text { - Interviews }\end{array}$ & 5hours/day \\
\hline 3. & $\begin{array}{l}\text { Radio } \\
\text { Banasthali }\end{array}$ & $\begin{array}{ll}\text { - } & \text { GrameenJagat,, } \\
\text { - } & \text { GoanGoanDhaniDhani, } \\
\text { - } & \text { Algoja } \\
\text { - } & \text { MileSurMera Tumhara } \\
\text { - } & \text { Apaji ki Siekh }\end{array}$ & $\begin{array}{l}\text { - Live-phone in } \\
\text { - Field recording } \\
\text { - Discussion } \\
\text { - Story with folk } \\
\text { music }\end{array}$ & 6hours/ day \\
\hline 4. & $\begin{array}{l}\text { Radio } \\
\text { Madhuban }\end{array}$ & $\begin{array}{l}\text { - } \text { Aashiyana, } \\
\text { - MeraGaonMeraAnchal, } \\
\text { - Apno Samaj, } \\
\text { - Gaon ri batain }\end{array}$ & $\begin{array}{ll}\text { - } & \text { Live-phone in } \\
\text { - } & \text { Field recording } \\
\text { - } & \text { Discussion } \\
\text { - } & \text { Interviews }\end{array}$ & 3hours/day \\
\hline
\end{tabular}




\begin{tabular}{|c|c|c|c|c|}
\hline 5. & Tilonia Radio & $\begin{array}{l}\text { - MGNREGA mein } \\
\text { chala, } \\
\text { - Manada Me Vishwas } \\
\text { Rakhlo }\end{array}$ & $\begin{array}{ll}\text { - } & \text { Discussion } \\
\text { - } & \text { Interviews } \\
\text { - } & \text { Field recording }\end{array}$ & 3hours/day \\
\hline 6. & Vagad Radio & $\begin{array}{l}\text { - Hamari Dharohar } \\
\text { - } \quad \text { Kheti Wadi, } \\
\text { - Lok Sangeet, }\end{array}$ & $\begin{array}{ll}\text { - } & \text { Discussion } \\
\text { - } & \text { Interviews } \\
\text { - } & \text { Field recording }\end{array}$ & 5hours/day \\
\hline
\end{tabular}

\subsubsection{Kamalvani 90.4 FM}

The programmes namely Radio maths, Maruras, Kuchh baten kuchh geet, Apni chaupal and
Khurjan has made the Kamalvani a popular radio station in the region. The programmes occupy 6 hours of airtime which is the $60 \%$ of total.

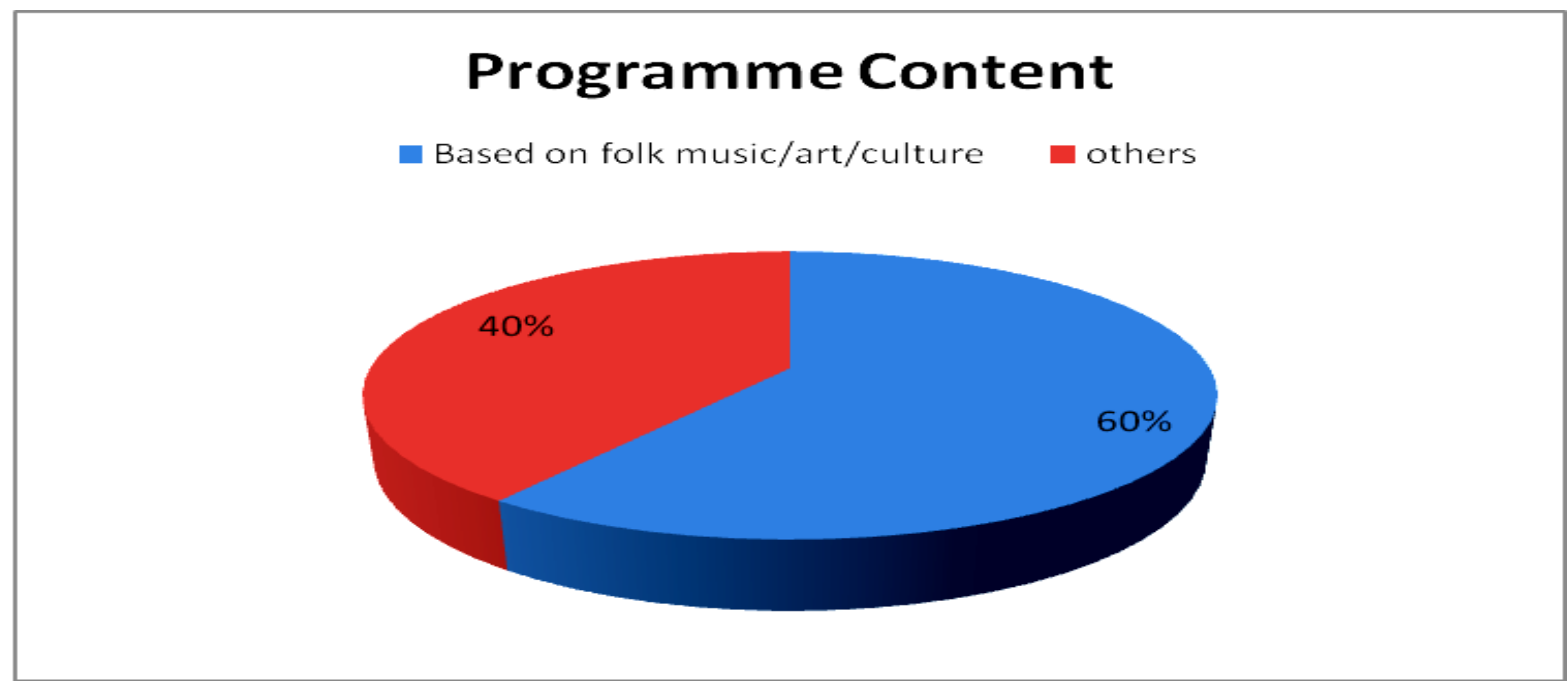

Figure 1.1

\subsubsection{Radio7 @90.4 FM}

The popular programmes on folk art and culture are Padharo Mhare Des, Dharti dhora ri, Ek mulakat, Chokho lage rajasthan, Potali kahaniyon $k i$ and Meethee bol. The programmes are being on aired for 5 hours dailywhich is near about $44 \%$ of total airtime (11.30 hours).

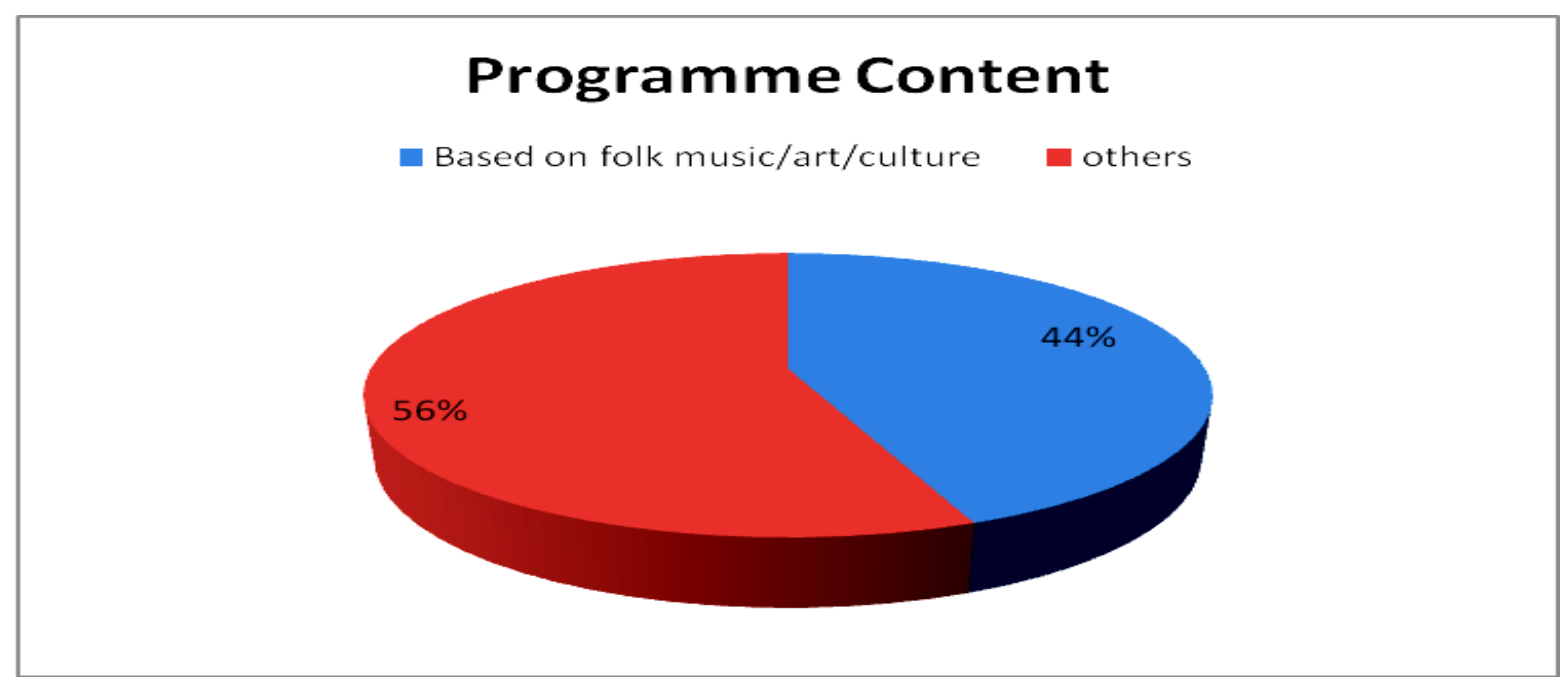

Figure 1.2 


\subsubsection{Radio Banasthali 90.4 FM}

The radio station broadcast Gramin Jagat, Apaji ki sikh, Gaon gaon dhani dhani, Algoja and Mile sur mera tumhara 6 hours daily which are very popular among the listeners of rural communities .

On the demand of the listeners these programs are repeatedly on aired. The analysis reveals half of the total airtime (12hrs/day) is given to these programmes which prove $50 \%$ programme content is pertaining to folk music, art and culture. (See figure 1.1)

\section{Programme Content}

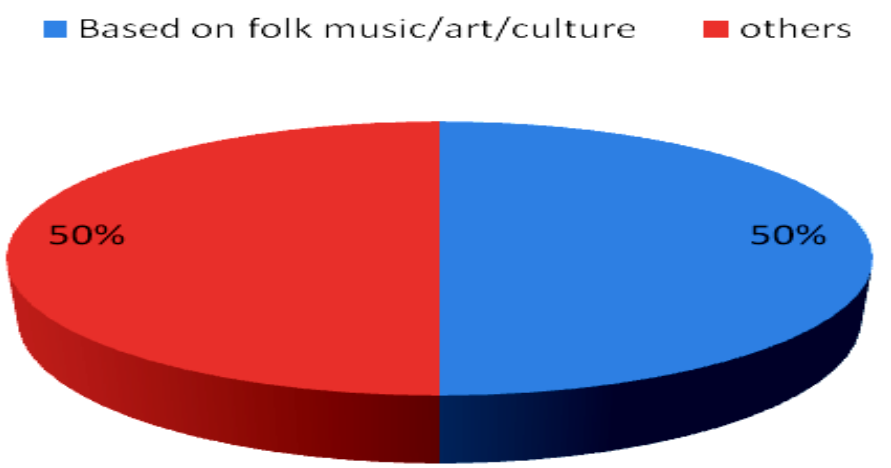

Figure 1.3

\subsubsection{Radio Madhuban 90.4 FM}

The station broadcast four programmes namely Aashiyana, Mera Gaon Mera Anchal, Apno Samaj and Gaon ri batain which focus on folk music and culture. The programmes are being on aired for 6 hours daily including repeat broadcast which is the $40 \%$ of total airtime (16 hours).

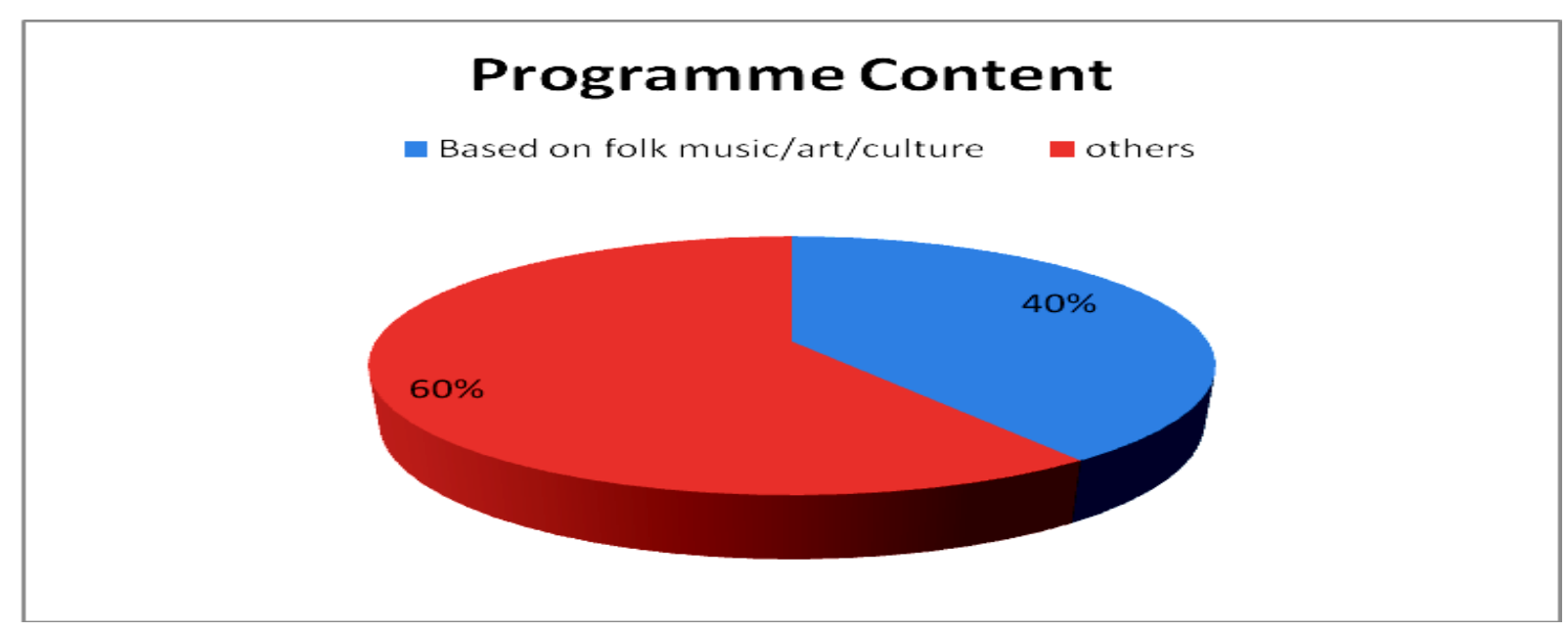

Figure 1.4

\subsubsection{Tilonia Radio 90.4 FM}

The station do not broadcast the programme with the specific titles but the content related folk songs are played in many programmes based on information related to musical instruments, festivals, agriculture, local music and culture. These are on aired 3 hours daily which contributes $43 \%$ of the total airtime (7hrs per day). 


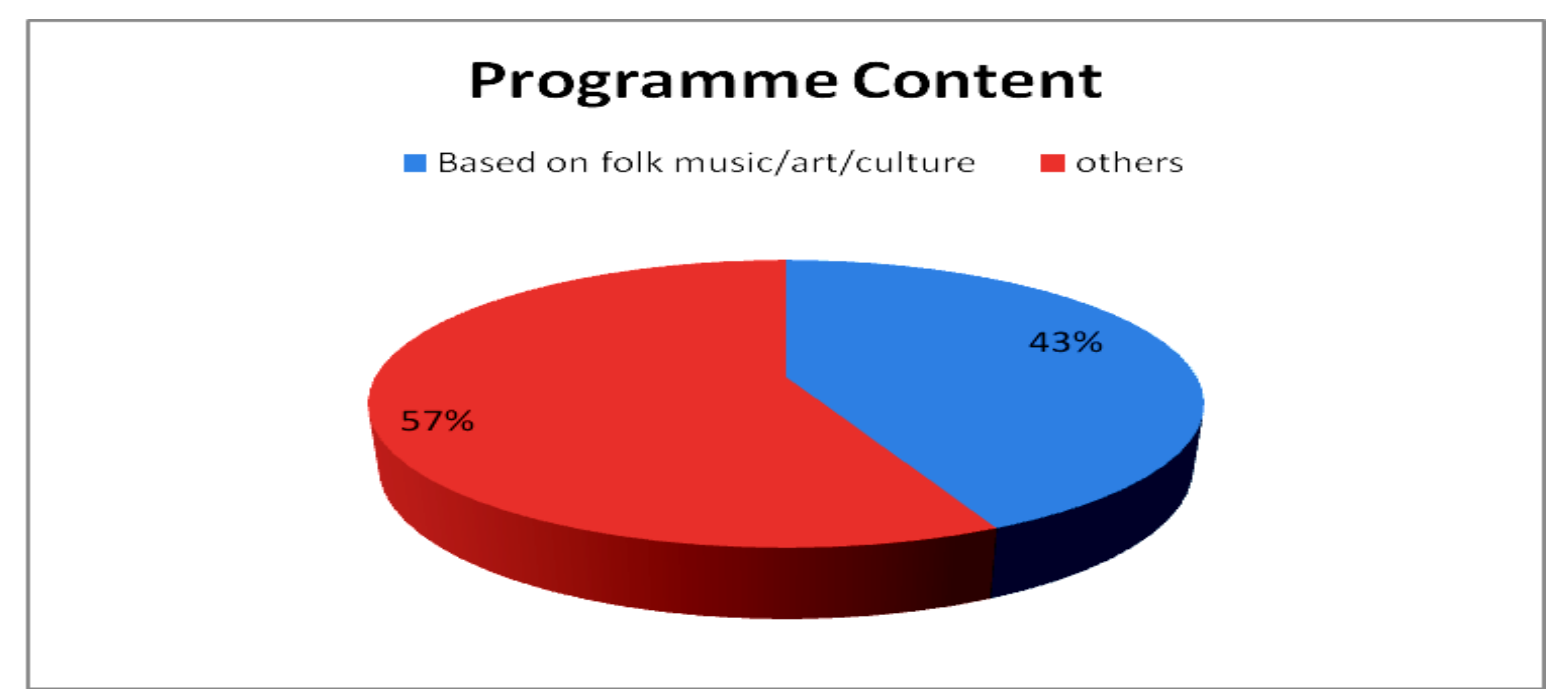

Figure 1.5

\subsubsection{Vagad Radio 90.8 FM}

Lok Sangeet, Hamari dharohar and Kheti-badi are the most popular programs at Vagad Radio and these are aired 5 hours daily which contributes $38 \%$ of the total airtime (13hrs per day).

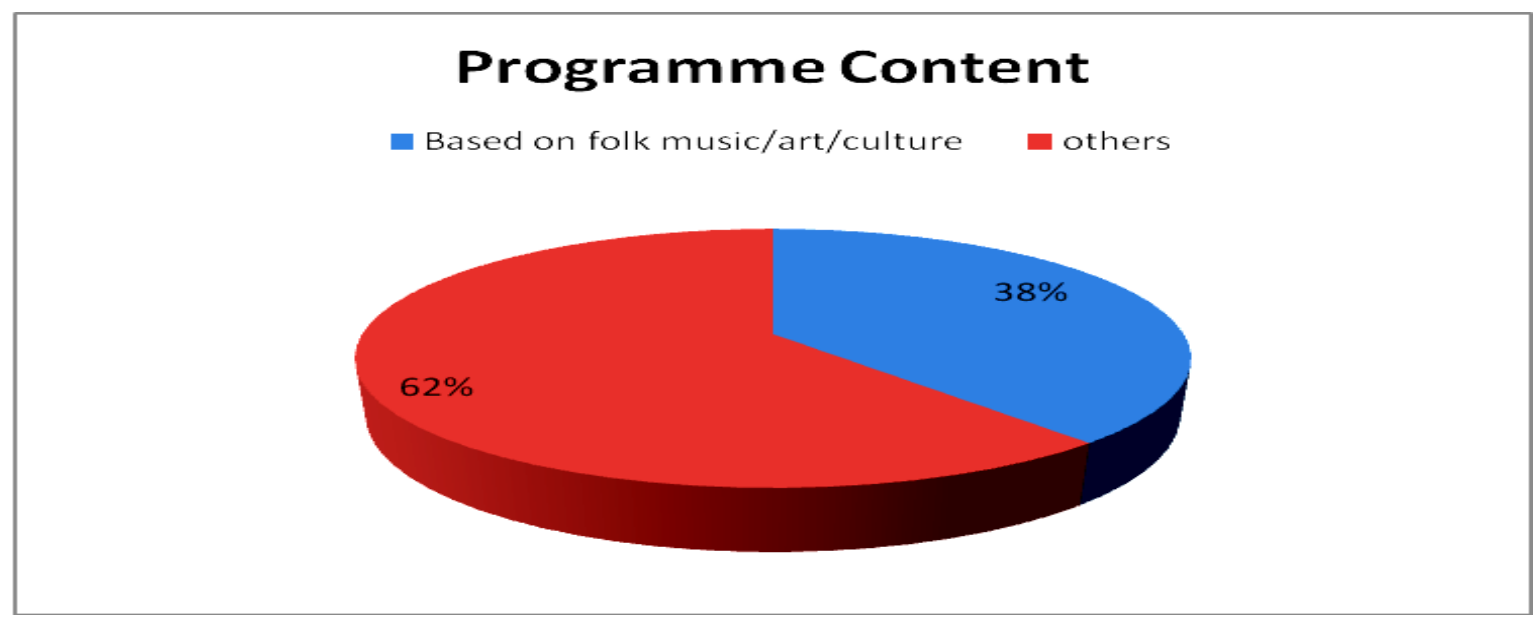

Figure 1.6

\subsection{Community radio activities and events}

Most of the radio stations have been carrying out the strategy of other community engagement activities like workshops, training programmes, fair, competition and camps effectively, in collaboration with other likeminded organisations. The radio stations organises activities frequently to engage and encourage the artists of the local community. The community members are always keen to participate and perform in such activities. The participants are given opportunity to showcase their talent through the airwaves. Listening own voice over FM radio station and sharing their talent is one of the biggest reward for

www.psychologyandeducation.net many of them.

\subsubsection{Kamalvani 90.4 FM}

Several folk artists from the local community are associated with the radio station. Vikas Nath of Fatehpur; koshalya and Gopaldas of Kolasia village; Nandini Tyagi of Sikar are among the popular who have given their voice to the station in the form of folk and devotional songs. Songs of folk deities like Ramdevji, Tejaji, Khatu shyamji and Salasarji are liked most which are composed and recorded by the local folk groups like Shyam bhajan mandali,Baba ramdev mitra mandal etc.

The station is also playing a proactive role in training the artisans and artists of local communities. More than 100 porters of local 
community have been trained in the electric charge machines used in the portery industries. The programme is being run for last two years in collaboration with the Khadi Evam Gramin Udyog Mission of Govt. of India under the programme of Portery Mission. Many of them are also participating in radio programmes and motivating others to join the programme. Other programmes like Telephone Upbhokta Jagrukta Karyakram with TRAI (Telephone Regulatory Authority of India) and Lok shikshan karykram with Khadi Gram Udyog have created a special identity of the station in the region.

\subsubsection{Radio 7 @ 90.4 FM}

The radio station is promoting the folk culture through the folk song, Interviews with the artists; and stories of historical places, architecture and craft. In the program Chokho lage Rajasthan, the station has interviewed with the popular artist of Jaipur. The famous dancer of Rajasthan Gulabo, the singer Ravindra Upadhyay; artists Meena Sapera, Raperiya Balam and Yash rajasthani are among them who have been interviewed by the station. In the programme Potli kahaniyon kithe stories of historical places like kumbalgarh,Mangarh and stories of famous art like paintings of Kishangarh have been onaired.Apart from this the stories of historic and popular personalities of Rajasthan like Maharana Pratapare also on aired. Many local theatre groups like Tononkira theatre academy are also associated with radio. The radio station is also promoting the famous blue pottery of Jaipur through the interviews with the artist associated with this art and craft. The radio station has organised a very special program for the special children wherein the children participated and gave performance on dance. The event was conducted in collaboration with some schools Jaipur.

\subsubsection{Radio Banasthali 90.4 FM}

The radio station has conducted a series of community engagement activities like sensitization programmes, workshops, exhibitions, fair and camps since inception. Hundreds of volunteers and artist have been trained in community radio with the support of National and international organizations like UNICEF, DST (Department of Science and Technology, Govt. of India), Save the Children (Jaipur) and CEMCA New Delhi. Many of them like Sita Gurjar ofHirapura village; Sonu Kumawat ofBanasthali village; Dharmraj Arya of Miyarampur Village; Maya Sharma of Banasthali Ranglal Mali of chikana; and Shanker Lal of Aliabad are working with the radio station as staff and volunteers.

Hundreds of local artists from the surrounding villages are associated with the radio station. Satya Narayan Raoand Ramji lal prajapat of Banasthali;Bal Kishan Rao of Dooni; Lalaram Rao of Dangarthal ; Shivraj of Shivrajpura;Pappu Kumar Prajapat of Newai; Nawal Dangi of Khandewatand Mukesh Saini of Newai village are among the popular one who can be heard frequently in the programs like Algoja and Mile SurMera Tumhara.

More than 500 folk songs have been archived by the radio station. The folk songs based on folk deities Tejai, Devnarayanji and Kalyanji are very popular among the communities and can be heard on tractors, in religious processions, family functions and marriages in the region. The local folk groups of Newai, Banasthali, Dangathal and khandevat like Tejaji ki Mandali and Devnarayan lok bhajan mandali have composed and recorded the songs.

Apaji ki Siekh is another popular programme among the listeners which is based on the songs written by eminent social reformer and founder of Banasthali Vidyapith (A pioneer institution for girl education), Pandit Hiralal Shastri Ji who is also known as Apaji. The songs are taken from his famous writings Apaji ke Geet in Rajasthani. The author point out the social evils and social inequality prevailed in the society and make appeal to stop the practices beautifully through the songs. The programme also raises awareness on girl education and social values. More than 50 songs has been composed and recorded by the 
artists of music department of the University. Recently the station has also conducted the programmes 'Full on Nikki' and 'Bachpan express' with support of UNICEF and BBC. The programme focuses on physical and psychological issues of adolescent and children.

\subsubsection{Radio Madhuban 90.4 FM}

The radio station focuses on serving the tribal community of region especially through the programmes based on field recordings like Gaon ri batain, Ashiyana and Apno Samaj which includes interviews and discussions with the villagers. The community anchor of station Ms. Usha Maheshwari is a well known name in these communities who has covered many villages in these programmes. The programmes are on-aired in the local language Marwari and Adivasi. The station organizes the events like competitions, training programmes, fest and puppet show to engage the local communities. The programme like Geet-Geet Mainand Meri Awaj hi Pahachan Haihas been the popular one in which thousands of local singers and artists has participated and many were rewarded by the station. Another popular programme is Antakshari in which the community anchors visits the villages and record traditional songs specially sung by women of tribal communities. The programme also covers schools wherein songs, poems and rhymes of school children are recorded.

Many folk singers and groups are associated with the station that keeps performing programmes for the station. Hundreds of recordings of these singers have been archived at the station. The local music band of Shyamji and Pukraj mali, Bhajan madali of Jeta Bharati and Indu Kanwar are very popular in the communities who keep recoding the programmes at radio station. The local singers and artists Hatam khan of Barmer; Preeti and Priya of Sirohi; Manju of Muthala village; Pooja ofKivarli village; Vinod of Tribal community are very popular in the communities and can be heard frequently on radio.

Recently the station has conducted the programmes 'Full on Nikki' and 'Bachpan express' with support of UNICEF and BBC. The programme focuses on physical and psychological issues of adolescent and children.

\subsubsection{Tilonia Radio 90.4 FM}

MGNREGA mein chala, Manada Me Vishwas Rakhloare very popular songs at Tilonia Radio.Popular singersGhazi khan, Anwar khan and Hameej khan of Manganiyars and Langas(a well known group of folk artists of jaisalmer)have recorded songs with the station. The station has also organized solar training programme in which the local community members are trained in solar lights and lamps. Many of them are also associated with the radio station as a singer and artist. The popular among local artists are Ramnivas of Akudia village,; Ratanlalof Padoda village; Sanwarmal of Tikavada village; Hemnath of Patan village; Moti of kochina; Satyanarayan of tilonia;Hanuman of kutchina; Anil of tilonia Nautidevi, Beeladevi, sitadevi, kamladevi, dhaapukaki, shehnaz and shakeela of tilonia village who can be heard in many programmes of station. Apart from this the station also organizes Puppet show and exhibitions to engage the community members. Folk singers of Kalbeliya and Banjara jaati are also associated with the station.

\subsubsection{Vagad Radio 90.8 FM}

Hundreds of folk songs have been composed and recorded by local singers. Satish Aacharya of Banswara, Prabhulal Sharma of Anandpuri Sukhlal and Bansilal of a local village are among the regular and popular one who have been associated with the radio station for last 2-3 years and can be heard frequently on radio. Recently in December 2019 the radio station organised a 'kavi sammelan' at grand level in which 10-12 well known poets of the region participated and since then they are associated with the CRS. The songs of folk diets like kallaji ke bhajanare very popular in the community which are recorded by the local folk groups of surrounding community. 


\section{Conclusion}

$40-60 \%$ programme content of community radio stations is based on folk music, art and culture of the locality which encourages the local singers and artists to perform and participate in programmes. The strength of programmes is local dialect which creates a bonding with the participants and allows the community members to express freely. The stations have achieved thousands of folk songs sung by local folk artists and groups which is a rare collection for the generations to come.

Due to the privatization and commercialization of media platforms theses local singers and artists are struggling to find the platform wherein they could showcase their talent and consequently they are losing their identity. The analysis of programmes and activities of community radio stations proves the community radio stations has emerged as community platforms wherein the community members participate in programmes and share the talent with millions. Listening own and sharing with million has always been a pride for these singers and artists. The radio stations are giving a new identity to many old and an identity to youngsters. Many other organizations like Ministry 0fInformation\& Broadcasting (India), UNICEF, UNESCO, DST, CEMCA and Save the Children have also come forward to support the CRS which allows innovative ways to preserve and promote the folk music, art and culture. The inculcation of socio-cultural values is another important aspect of these programmes. Sometime folk songs become an effective medium of teaching the values which has a greater impact on the community members. Some of the local artists are also associated with the stations as staff and volunteers which have become the source of livelihood. Although indigenous cultural values are being promoted by the community media; more efforts are required before our cultural values are lost in the winds of global culture.
[1] Atton, C. (2002) Alternative Media London: Sage.

[2] Archana Bhatt \& S. K. Kashyap , "Prioritizing Needs for Community Radio Broadcast for Livelihood Improvement: A Study of Pantnagar Janvani Community Radio Service of Uttarakhand “, International Journal of Applied and Natural Sciences (IJANS), Vol. 5, Issue 5,pp. 63-72

[3] Dagron A. (2001), "Making waves: stories of participatory communication for social change". New York: The Rockefeller Foundation.

[4] Dutta, A., \& Ray, A. (2009, January 29). Community Radio: A Tool for Development of NE. The Assam Tribune [Guwahati], p. 4 Edit Page.

[5] Francis, L., \& Livingstone, C. (2019). Gambling's community contributions: does the community benefit?. Addiction Research \& Theory, 1-14.

[6] Fraser, C., \&Estrada, S. R. (2001). Community Radio Handbook.UNESCO.

[7] Bhavna Pathak, "The Community Radio Movement in India: Challenges and Opportunities ", International Journal of Communication and Media Studies (IJCMS), Vol. 9, Issue 2, pp. 1-8

[8] Howley, K. (2010). Understanding Community Media . London: SAGE

[9] Jallov, B. (2012). Empowerment Radio Voices Building a Community (1st ed.). Gudhjem: Empower house.

[10] Mayoux, L. (2005). Gender Equity, Equality and Women's Empowerment: Principles, Definitions and Frameworks.

[11] McQuail, D. 1994. Mass communication theory: An introduction. London: Sage.

[12] Page, N., \& Czuba, C. E. (1999). Empowerment: What Is It? Journal of Extension, 37(5).

[13] Pavarala, V., \& Malik, K.K. (2007). Other Voices: The struggle for Community 
Radio in India. New Delhi: Sage Publications.

[14] Pankaj S. Parsania, Nischal M. Chavda \& Krunal C. Kamani, "Information and Communication Technology \& Its Impact in Improving the Teaching and Learning of English Language ", International Journal of Computer Science Engineering and Information Technology Research (IJCSEITR), Vol. 5, Issue 3, pp. 1-6

[15] Rennie, E. (2006). Community media: a global introduction. Lanham, MD: Rowman \&amp;

[16] Littlefield

[17] Rowlands, J. (1997), Questioning Empowerment. Working with Women in Honduras. UK: Oxfam.

[18] Rogers, E.M. 1983. Diffusion of innovations, 3rd Edition. New York: Free Press.

[19] Sen A. Airwaves are for everyone, The Hindu, July 28, 2011

[20] Florence R. Katingi \& Agnes W. Kibui , "Challenges that Affect Academic Performance of Children with Special Needs in Inclusive Settings in UMOJA Zone, Embakasi District, Nairobi County, Kenya ", BEST: International Journal of Humanities, Arts, Medicine and Sciences (BEST: IJHAMS), Vol. 3, Issue 12, pp. 57-64

[21] Sharma, L., Rathore, H., \& Sharma,G. (2020) 'Empowering Rural Communities through Community Radio Training Programmmes: A Case Study of Banasthali Community FM Radio Station', International Journal of Communication and Media Studies (IJCMS), 10(3), pp. 112 [Online]. Available at: www.tjprc.org (Accessed: 16th April 2020).

[22] Stewart-Withers, R., Banks, G., McGregor, A., \& Meo-Sewabu, L. (2014). Qualitative Research. In R. Scheyvens (Ed.), Development Fieldwork - A Practical Guide. London: SAGE
Publications Ltd.

[23] Manisha Tharu \& Ram Ganesh Yadav , "Effects of Technological Development through Electronic Communication in Women Empowerment ", International Journal of Humanities and Social Sciences (IJHSS), Vol. 7, Issue 5,pp. 93-100

[24] Mradula Tiwari, Ritu Chakravarty \& Jayant Goyal , “Availability and Accessibility of Information Communication Technology (ICT) among Dairy Farmers in Uttarakhand, India “, IMPACT: International Journal of Research in Applied, Natural and Social Sciences (IMPACT: IJRANSS), Vol. 2, Issue 7, pp. 47-52

[25] Traber, M. 1985. 'Alternative Journalism, Alternative Media', Communication Resource, 7 October. London: World Association for Christian Communication.

[26] White, S. 1994. Participatory communication: Working for change and development. New Delhi: Sage.

\section{Internet Sources}

[27] http://www.mib.gov.in/broadcasting/comm unity-radio-stations

[28] http://www.unesco.org/webworld/publicati ons/community_radio_handbook.pdf

[29] https://www.youthkiawaaz.com/2011/02/c ommunity-radio-for-rural-development

[30] http://unesdoc.unesco.org/images/0023/00 2330/233084E.pdf

[31] http://cemca.org.in/ckfinder/userfiles/files/ Innovations

[32] http://www.youngindia.net.in

[33] http://www.amarc.org/documents/articles/e valuation_2007.pdf

[34] http://www.banasthali.org/banasthali/wcm s/en/home/lower-menu/campus tour/communication/index.html

[35] www.unicef.org 
[36] http://www.banasthali.org/banasthali/wcm s/en/home/lower-menu/campus-

tour/communication/index.html

[37] https://www.barefootcollege.org/a-

community-radio-station-broadcast-by-

and-for-rural-villagers/

[38] https://edaa.in/site/tilonia-radio

[39] https://vaagdhara.org/vagad-radio-90-8-

fm-live-community-radio-vaagdhara

[40] https://radiomadhuban.in

[41] http://kamalnishtha.org/kamalvani

[42] http://www.iisjaipur.org/fm7.htm 